
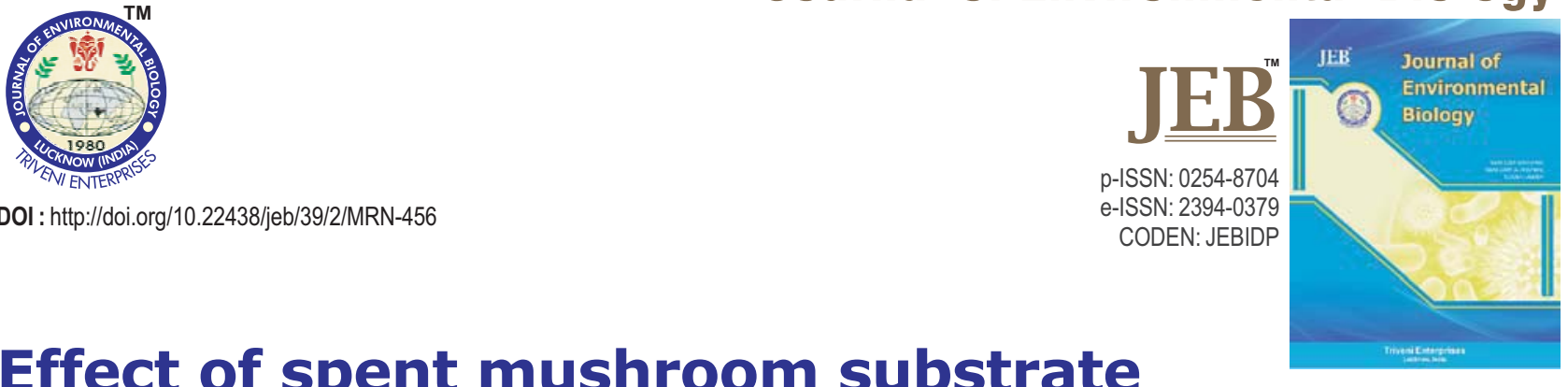

\title{
Effect of spent mushroom substrate and waste paper briquette on methane production from anaerobic digestion
}

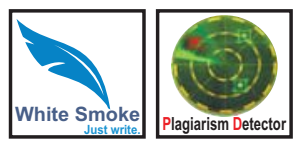

\section{Authors Info \\ Sethumadhavan P. and Arul Mozhi Selvan V.* \\ Department of Mechanical Engineering, National Institute of Technology, Tiruchirappalli - 620 015, India \\ *Corresponding Author Email : arulmozhi@nitt.edu}

Key words

Briquetting process

Co-digestion

Methane production

Spent mushroom substrate

Waste paper

Publication Info

Paper received : 08.09.2016

Revised received : 13.04.2017

Re-revised received: 12.09 .2017

Accepted: 29.09 .2017

\section{Abstract}

Aim : The objective of the study was to assess the methane yield of briquettes prepared from spent mushroom substrate and waste paper mixed in equal proportion.

Methodology : Spent mushroom substrate after cultivation of Pleurotus florida on rice straw and waste paper was milled to less than $5 \mathrm{~mm}$ size. They were briquetted in equal mass proportion in a screw type machine. Briquette and individual substrates were assessed for their methane potential under anaerobic conditions in $125 \mathrm{ml}$ bottles incubated at $37^{\circ} \mathrm{C}$ for 60 days. Data was statistically analyzed using analysis of variance. Dunnett's posthoc test was used to assess the significance $(P<0.05)$.

Results : When waste paper was co-digested with spent mushroom substrate as powder, methane yield of $168 \mathrm{ml} \mathrm{CH}_{4} \mathrm{~g}^{-1} \mathrm{VS}$ was observed. When spent mushroom substrate - waste paper as briquette was used, highest methane yield of $250 \mathrm{ml} \mathrm{CH}_{4} \mathrm{~g}^{-1} \mathrm{VS}$ was observed. Size reduction in briquetting process made the cellulose and other components of plant cell walls more accessible to the microorganisms. SEM and FT-IR studies confirmed the impact of briquetting as a pretreatment step. Volatile fatty acid (VFA) to alkalinity ratio was observed as 0.26 at the end of digestion of briquettes, which confirmed the process stability.

Interpretation : Methane yield from anaerobic digestion process was found to be enhanced by briquetting of spent mushroom substrate and waste paper.
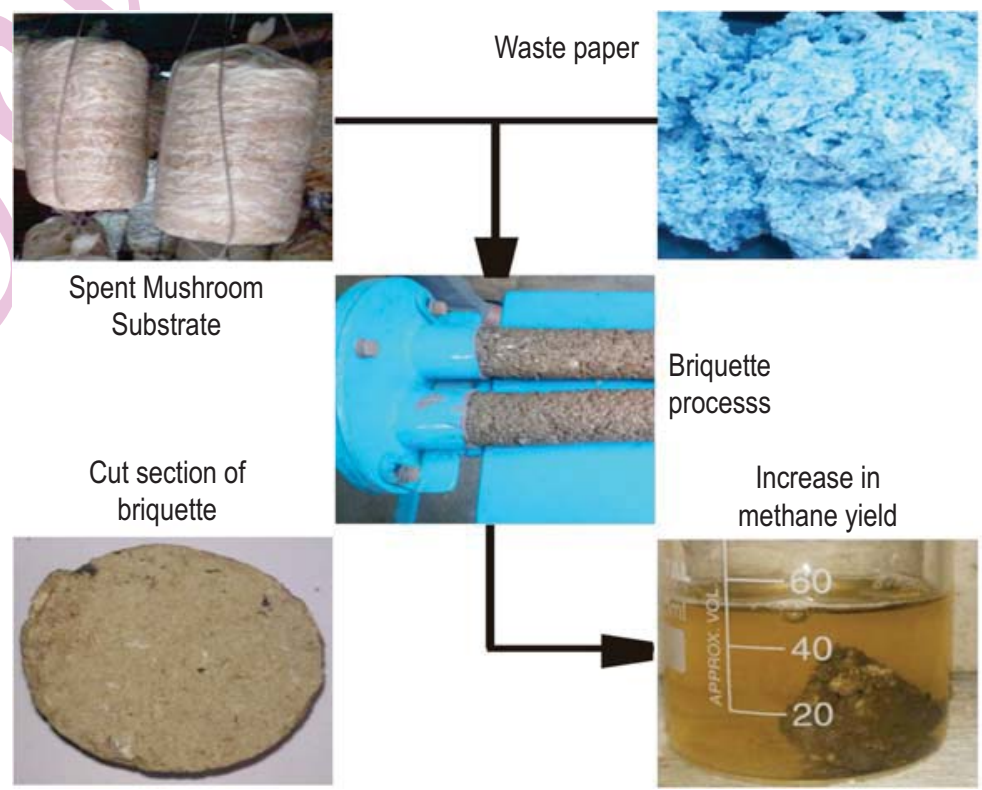


\section{Introduction}

A source of food which can create local employment opportunity and contribute to sustainable and environmental friendly waste management can be a boon to the developing community. Mushroom production is a fast growing food industry which utilizes waste substances for its growth. Mushroom production has been gaining importance in India as agro wastes like rice straw, sugar cane bagasse and wheat straw are the basic raw material used as a bed on which mushroom spawns are inoculated for harvesting edible mushrooms. Rice straw was used as bed material in cultivation of Pleurotus florida mushroom and after three flushes of harvesting the bed material was discarded as spent mushroom substrate (Holkar and Chandra, 2016). Generally, the spent mushroom substrate waste is spread on fields to degrade as passive composting and to remove inorganic salts. Water leaching from spent mushroom substrate percolates into soil and leads to negative environmental impact (Guo and Chorover, 2006).

In developing countries like India, spent mushroom substrate is thrown in open fields as land supplement or mixed with cow dung and utilized as organic manure. Even in such cases, spent mushroom substrate is dumped for a long time on land before disposal. Mismanagement of spent mushroom substrate leads to environmental problems (Zhang et al., 2017). For each $\mathrm{kg}$ of mushroom produced, $5 \mathrm{~kg}$ of spent mushroom substrate is produced. With the availability of spent mushroom substrate throughout the year, usage of this waste as raw material for biofuel production is sustainable. On analysis of spent mushroom substrate, it was observed that carbon and nitrogen were present in levels comparable to animal manure like cow dung to consider it as a biogas generation resource. Earlier study pointed out the growing concern of greenhouse gas emission from organic matter in municipal solid waste in all Indian megacities generating @ 0.545 to 1.1 kg capita ${ }^{-1} \mathrm{~d}^{-1}$ (Jha et al., 2008). It was observed that decentralized waste treatment at source for anaerobically digesting organic waste and waste paper can reduce burden on landfill by over $90 \%$. It can also generate biogas to substitute fossil fuel consumption. Anaerobic digestion process to treat traditional waste substrates like cow dung was studied for enhancement of biogas production and was reported that agricultural residues when used as supplement to cow dung as feedstock for biogas plants doubled the gas production (Yadvika et al., 2004). Organic loading rate was considered as important factor to enhance biogas production and it was reported that a quantity of $2.91 \mathrm{~kg} \mathrm{VS} / \mathrm{m}^{3} /$ day of feedstock generated a yield of $0.36 \mathrm{~m}^{3}$ of biogas/day. The requirement of biogas for domestic cooking purpose was estimated as $0.33 \mathrm{~m}^{3} /$ person/day (Ramachandra et al., 2000). Hence, it was observed that around $3 \mathrm{~kg} \mathrm{~d}^{-1}$ of organic waste generation should take place in domestic sector to consider biogas as a sustainable fuel for cooking in households. One important parameter observed for enhanced microbial activity in anaerobic digestion is carbon to nitrogen $(\mathrm{C}: \mathrm{N})$ ratio. Microbes need a C:N ratio of 20 to $30: 1$ which can be obtained by combining different waste materials (Yadvika etal., 2004).
A study of co-digesting algal sludge and paper waste blended at 1:1 ratio to get a C:N ratio of 18:1 resulted in optimum generation of $1170 \mathrm{ml} \mathrm{CH}_{4} / \mathrm{l}$ day (Yen and Brune, 2007). Waste paper occurs as a predominant component of solid waste generated at urban areas and could not be recycled due to its soiled moist condition. It only adds load on landfills. High C:N ratio of waste paper acts as a barrier for its anaerobic digestion. Rice straw, a lignocelluloses material, has been studied for its suitability for anaerobic digestion and reported that physical, thermal and chemical pretreatment methods positively affected their digestibility (Chanakya et al., 2009). During cultivation, Pleurotus florida mushroom uses cellulose, hemicellulose and some of them attack lignin. This changes the structural parameters and lowers $\mathrm{C}$ : $\mathrm{N}$ ratio of feedstock. Co-digestion of high $\mathrm{C}: \mathrm{N}$ ratio waste paper with low $\mathrm{C}: \mathrm{N}$ ratio spent mushroom substrate was considered beneficial for methane production. Even though recent research work is available on extrusion as mechanical pretreatment for rice straw (Chen et al., 2014). To our knowledge research on the briquetting of spent mushroom substrate and to improve methane yield is meager. This could be a value addition to ecofriendly mushroom industry.

Hence in the present study, elemental composition of raw materials, changes in morphology, surface functional groups due to pretreatment, biochemical methane production, extent of biodegradability and process stability were studied with the aim of assessing improvement in methane production due to briquetting process.

\section{Materials and Methods}

Sample collection and processing : Cow dung for this experimentation was obtained from a nearby cowshed. Untreated rice straw and spent mushroom substrate after cultivation of Pleurotus florida mushroom on rice straw were obtained from an active mushroom industry at Trichy, India. Waste paper was collected from domestic municipal solid waste yard. Materials were collected from the generation point itself to avoid soil and other contamination. Parts of wastes were sun dried for 7 days and dried material was milled to less than $5 \mathrm{~mm}$ size in a ball mill and used for characterization.

Briquetting process : A single screw extruder cum briquetting machine (ERS-BMB 2, Ecoster, India) was used for briquetting of spent mushroom substrate and waste paper mixture. The briquetting machine was fabricated with a screw chamber of size $100 \mathrm{~mm}$ in diameter (D) and $300 \mathrm{~mm}$ length (L), screw speed of 24 rpm and driven by a $1.5 \mathrm{~kW}$ motor. Dried spent mushroom substrate and waste paper were mixed thoroughly in equal proportion by weight and ball milling was made. The milled mix was stored in Ziplock bags. $1 \mathrm{~kg}$ of spent mushroom substrate-waste paper mix was sprayed with deionized water to obtain the moisture of 20 to 30 $\%$ and briquettes were formed of $50 \mathrm{~mm}$ diameter through opening at the end of the die. To increase the density of briquettes formed, the dies were closed for one min after feeding the waste inside the screw hopper using a lid fabricated for this purpose and the lid was 
opened to get closely packed briquettes. The obtained briquettes were then sun dried for 6 days to remove the moisture. The dried briquettes were then stored in air tight zip lock bags at room temperature for anaerobic digestion experiments.

Analytical techniques : The elemental composition of the substrates was determined for carbon, nitrogen, hydrogen and sulfur components using Elementar Vario EL III. The oxygen content was considered as a balance component in the samples. Total solids (TS) was estimated by drying weighed quantity of sample in hot air oven at $105^{\circ} \mathrm{C}$ for $24 \mathrm{hrs}$ and weight loss over initial weight was estimated as TS (APHA, 2012). Volatile solids (VS) was determined by igniting the sample obtained after TS estimation in a muffle furnace at $550^{\circ} \mathrm{C}$ for $2 \mathrm{hrs}$ and weight lost on ignition represents the volatile solids (APHA, 2012). A digital pH meter was used to measure $\mathrm{pH}$ of the slurry. Weighing of waste material was carried out using electronic weighing machine (Model Shimadzu AUX 220). Biogas generated in the vials during the experiment was collected using gas tight syringe to measure the quantity. Methane content from the anaerobic digestion process was measured by injecting the gas into water displacement bottle containing $5 \% \mathrm{NaOH}$ solution. The composition of biogas for the predominant components $\mathrm{CH}_{4}$ and $\mathrm{CO}_{2}$ were cross checked using a Gas Chromatograph (Mayura Analytical, India). Thermal conductivity detector (GC-TCD) and stainless steel column housing HayeSep A polymer column was used under isothermal conditions at $60^{\circ} \mathrm{C}$. Hydrogen gas was used as carrier maintaining flow rate of $30 \mathrm{ml} \mathrm{min}^{-1}$. The sample gas concentration was compared to a standard gas mixture consisting of $59.4 \% \mathrm{CH}_{4}$ and $40.6 \% \mathrm{CO}_{2}$. Titration with $0.1 \mathrm{~N}$ sulfuric acid was followed to determine volatile fatty acids (VFA) and total alkalinity (TA) after completion of digestion process of 60 days. The results of acid (VFA) and alkalinity were determined and expressed as a ratio which indicates the state of stability of anaerobic digestion process. Scanning Electron Microscopy (SEM) (Model HITACHI S-3400 N) was used to observe the surface morphology of untreated rice straw, spent mushroom substrate after mushroom production and spent mushroom substrate-waste paper briquette to assess the effect of biological mushroom making process and briquetting process as a pretreatment step before anaerobic digestion. The samples were sputter-coated with gold and micrographs taken. Fourier transform infrared (FT-IR) measurements were carried out using BRUKER spectrometer equipped with ATR in the range of 4000 $500 \mathrm{~cm}^{-1}$ with a resolution of $4 \mathrm{~cm}^{-1}$ to observe the changes in functional groups of rice straw after mushroom production.

Biochemical methane potential assessment : Samples were taken in duplicates for the biochemical methane potential study. A total of 12 vials were used in this study. The wet anaerobic digestion process was carried out in $125 \mathrm{ml}$ capacity glass serum vials with working volume of $50 \mathrm{ml}$ in which 7 days old digested slurry from active anaerobic digester incubated at $37 \pm 1^{\circ} \mathrm{C}$ was added as inoculum. Spent mushroom substrate and waste paper were tested as single feedstock and spent mushroom substrate-waste paper briquette was tested as co-digestion substrate to the inoculum at a loading rate of $2 \mathrm{~g} \mathrm{VS}$ and a inoculum to substrate ratio of 0.5 . Distilled water was used to top up a working volume of $50 \mathrm{ml}$. The vials were then flushed with nitrogen to remove traces of air on the headspace. Immediately rubber stoppers were placed and firmly crimped with aluminium seal using a cap sealing tool. The bottles were then labeled and kept in inverted position to ensure that there was no leakage. The bottles were incubated at $37 \pm 1^{\circ} \mathrm{C}$ in an incubator. Quantity of biogas produced was measured daily during initial 10 days and on alternate days during the next 50 days using gas tight syringe. The inoculum was separately maintained in a biochemical methane potential bottle to act as a control and subtracted from gas yield of the feedstock material. The cumulative methane yield for the feedstock after $\mathrm{CO}_{2}$ scrubbing was calculated as $\mathrm{ml} \mathrm{CH}_{4} \mathrm{~g}^{-1}$ VS. Methane produced was corrected to the volume at standard temperature and pressure $(273 \mathrm{~K}, 101.325 \mathrm{~Pa})$. Theoretical methane potential was estimated using Buswell formula based on the elemental composition of substrates and biodegradability was calculated from comparison of experimental and theoretical methane yield.

Statistical analysis : Data analysis was done by one way analysis of variance (ANOVA) at $95 \%$ confidence interval for this completely randomized design experiment. For the location of differences between treatments and control, Dunnett's post-hoc test was carried out.

Table 1 : Comparison of chemical composition of materials used for anaerobic digestion

\begin{tabular}{|c|c|c|c|c|}
\hline Component & $\begin{array}{l}\text { Waste } \\
\text { paper }\end{array}$ & $\begin{array}{l}\text { Spent mushroom } \\
\text { substrate }\end{array}$ & Cow dung & $\begin{array}{l}\text { Spent mushroom } \\
\text { substrate and waste paper }\end{array}$ \\
\hline Total solids (\%) & 20.56 & 24.43 & 15.15 & 90.76 \\
\hline Volatile solids (\%) & 90.37 & 64.63 & 95.52 & 72.44 \\
\hline Carbon (\%) & 36.20 & 19.60 & 22.41 & 33.80 \\
\hline Hydrogen (\%) & 5.0 & 4.80 & 4.36 & 4.8 \\
\hline Nitrogen (\%) & 0.13 & 1.55 & 1.83 & 0.83 \\
\hline Sulphur (\%) & 0.07 & 0.16 & 0.20 & 0.12 \\
\hline C:N Ratio & $278: 1$ & $12: 1$ & $13: 1$ & $40: 1$ \\
\hline
\end{tabular}




\section{Results and Discussion}

One of the important operating variable for anaerobic digestion was C:N ratio of the substrates and a ratio of 20 to $30: 1$ was suggested for biogas fermentation (Weerayutsil et al., 2016). The C:N ratio in this study was lesser than optimum for cow dung and spent mushroom substrate but was high for waste paper. $A$ carbon to nitrogen ratio of rice straw before utilization for mushroom production was unfavorable at 64.1:1 (Zhang et al., 2016). After utilization for mushroom production, the $\mathrm{C}: \mathrm{N}$ ratio of rice straw, which was transformed into spent mushroom

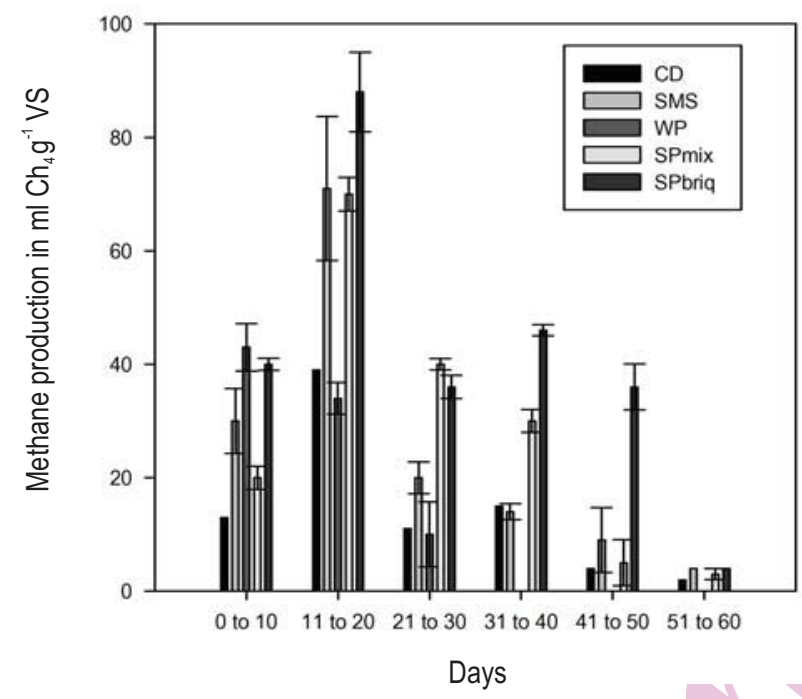

Fig.1 : Methane production rate at every 10 days interval for cow dung (CD) , Spent Mushroom Substrate (SMS), Waste paper (WP), spent mushroom substrate-waste paper mixture $\left(\mathrm{SP}_{\text {mix }}\right)$ and spent mushroom substrate-waste paper briquette $\left(\mathrm{SP}_{\text {briq }}\right)$. Error bars represent standard deviation of tests done in duplicate substrate, dropped down to 12:1 nearer to the range of cow dung. A substrate with low $\mathrm{C}: \mathrm{N}$ ratio can lead to accumulation of high volatile fatty acids thereby, resulting in failure of anaerobic digestion process. A substrate with high $\mathrm{C}: \mathrm{N}$ ratio can cause rapid consumption of nitrogen by methanogens leading to lesser gas production (Yan et al., 2015).

Carbon to nitrogen ratio of substrates can be adjusted and made suitable for anaerobic co-digestion. From Table 1 it can be observed that the $\mathrm{C}: \mathrm{N}$ ratio for the mixture of spent mushroom substrate and waste paper at a ratio of 1:1 dropped to 40:1 when compared with individual component of waste paper of 278:1.

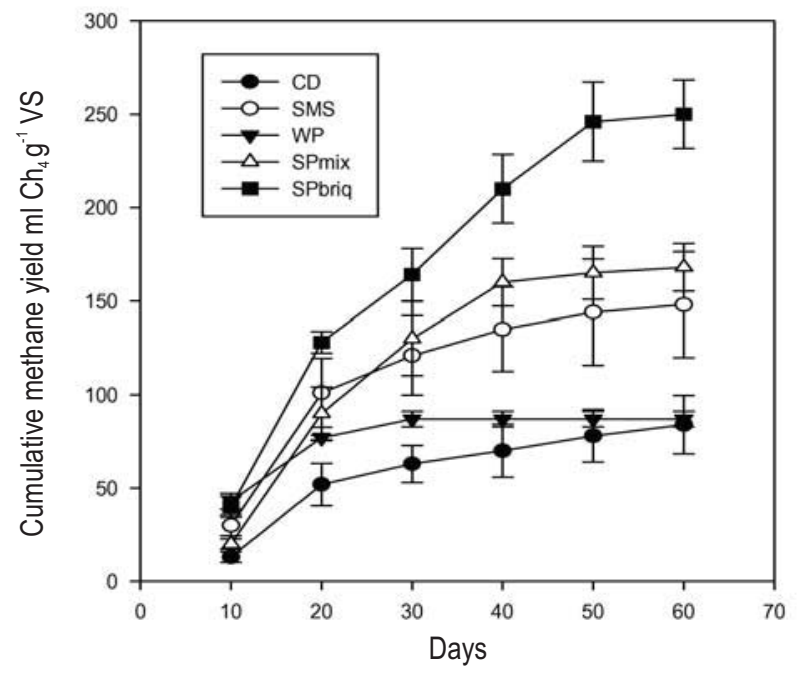

Fig.2 : Cumulative methane yield for 60 days period. Error bars represent standard deviation of tests done in duplicate

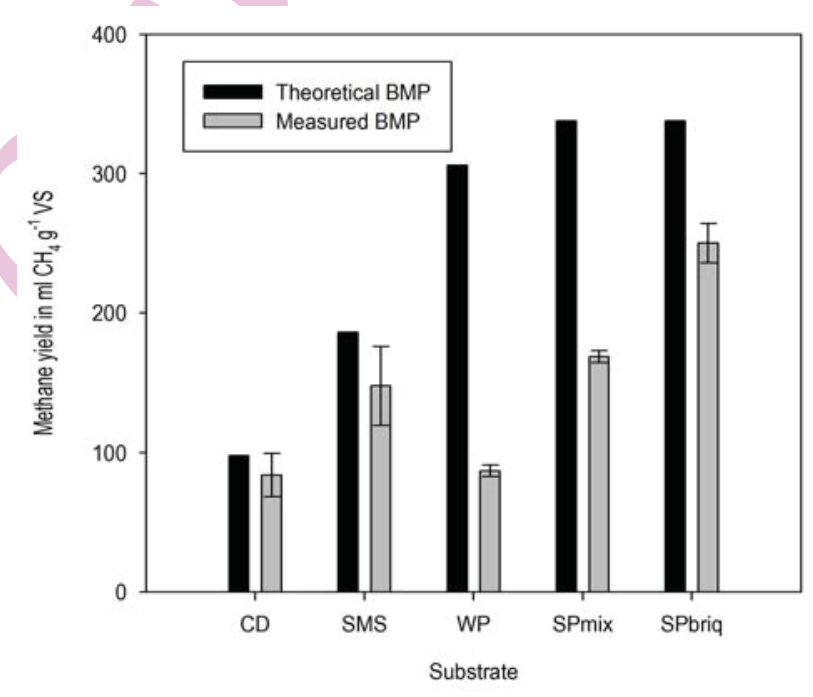

Fig. 3. Biodegradability of substrates based on experimental and theoretical biochemical methane potential values. Error bars in measured biochemical methane potential indicates standard deviation of tests done in duplicate 

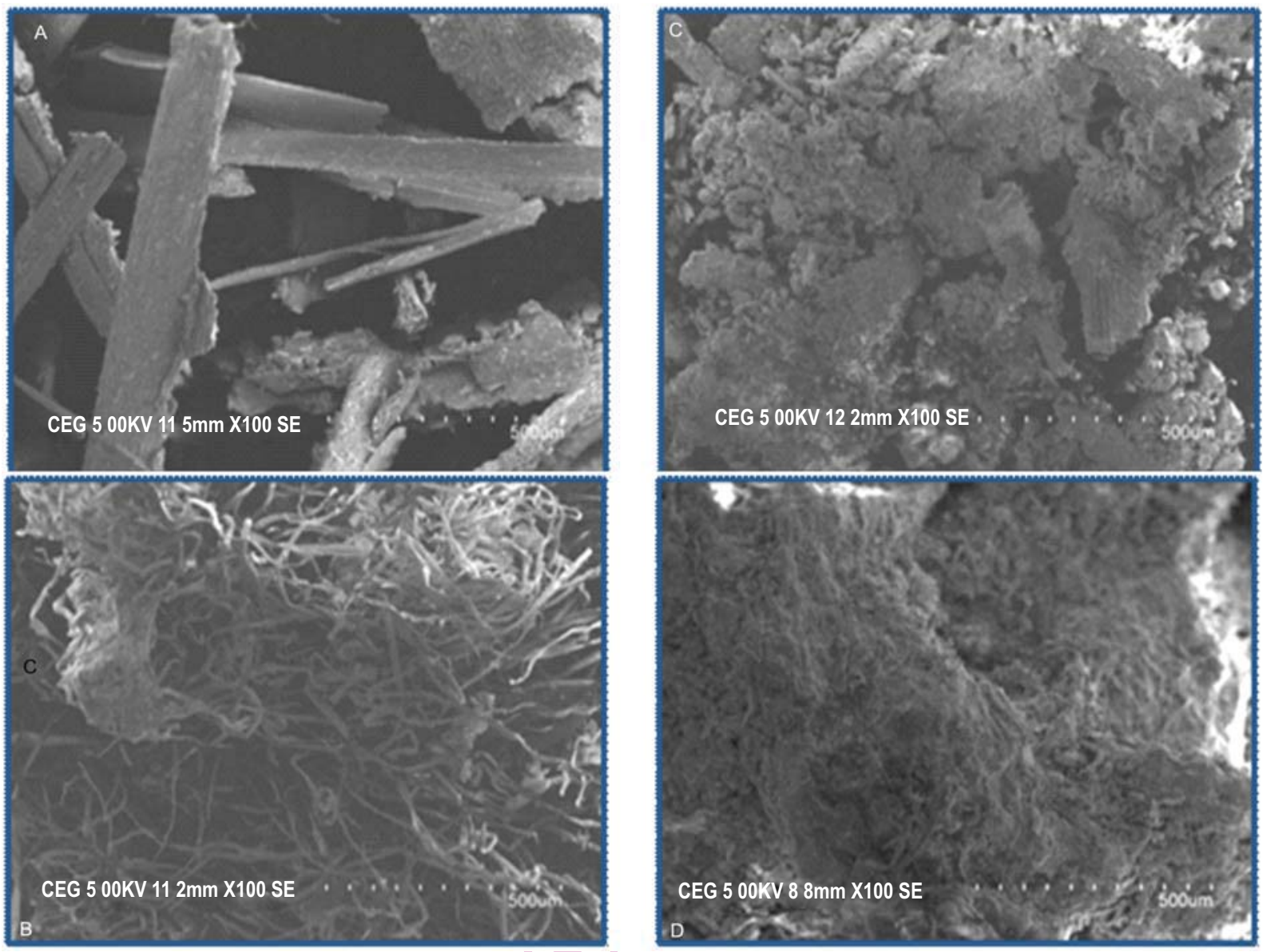

Fig. 4 : (A) SEM images of untreated rice straw; (B) lignin structure of waste paper; (C) smooth surface in spent mushroom substrate; (D) dense surface structure in spent mushroom substrate-waste paper briquette

This made the spent mushroom substrate-waste paper mix nearer to the optimum C:N ratio. There was no change in the elemental composition in spent mushroom substrate and waste paper mix due to briquetting process and hence, there was no change in $\mathrm{C}: \mathrm{N}$ ratio between mix and the briquettes.

Theoretical methane yield of organic waste can be estimated form their elemental composition (Achinas and Euverink, 2016; Dussadee et al., 2017). Experimental data from the biochemical methane potential assay can then be compared with the theoretical values to assess the efficiency of co-digestion of different substrates. The theoretical biochemical methane potential of spent mushroom substrate and waste paper briquette showed increase in potential of $81 \%$ over spent mushroom substrate and $10 \%$ over waste paper.

The highest cumulative methane yield was from spent mushroom substrate-waste paper briquette with $250 \mathrm{ml} \mathrm{CH}_{4} \mathrm{~g}^{-1}$ VS on day 60 biochemical methane potential measurement period (Figs 1 and 2). There was an increase in methane yield of
$49 \%$ from the briquettes when compared with anaerobic digestion of spent mushroom substrate-waste paper in powder form. Improvement in methane yield of $20 \%$ has been reported for alkali pretreatment on rice straw (Shetty et al., 2017). The mechanical, chemical and biological treatment of rice straw during mushroom production process favors better surface area available for degradation by bacteria and a better $\mathrm{C}: \mathrm{N}$ ratio, leading to higher methane yield. The methane yield of $87 \mathrm{ml} \mathrm{CH}_{4} \mathrm{~g}^{-1}$ VS from waste paper was close to the value of $84 \mathrm{ml} \mathrm{CH}_{4} \mathrm{~g}^{-1} \mathrm{VS}$ reported for untreated newsprint paper (Walter et al., 2016). There was an increase in methane yield over waste paper as a single substrate by $187 \%$ for equal proportions of spent mushroom substrate-waste paper briquette as a feedstock. It was observed that the waste paper as well spent mushroom substrate powder formed a scum on top layer of slurry retarding methane generation rate. This scum formation was found absent in the spent mushroom substrate-waste paper briquette and probable reason for higher methane yield. The methane production ceased around 20 days for waste paper as a single substrate, found extended to full experimental digestion period of 60 days when 

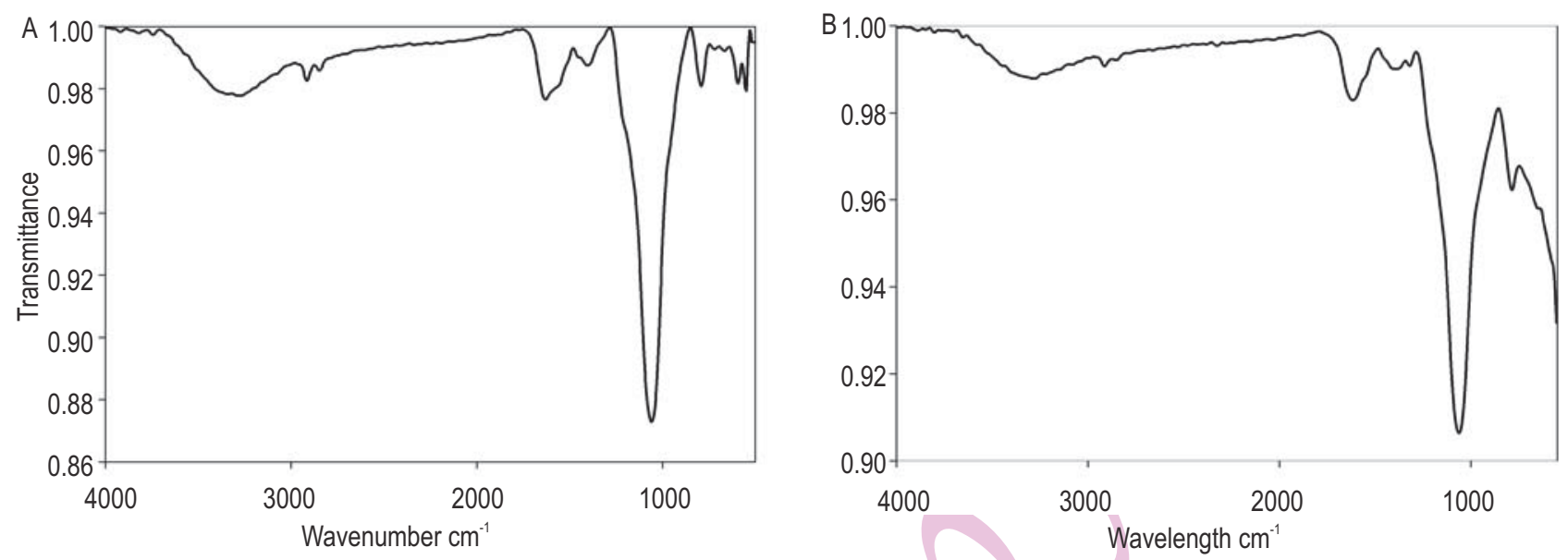

Fig. 5 : FTIR spectra of untreated rice straw $(A)$ and spent mushroom substrate $(B)$ showing variation in surface chemistry due to the effect of biological mushroom production process on rice straw

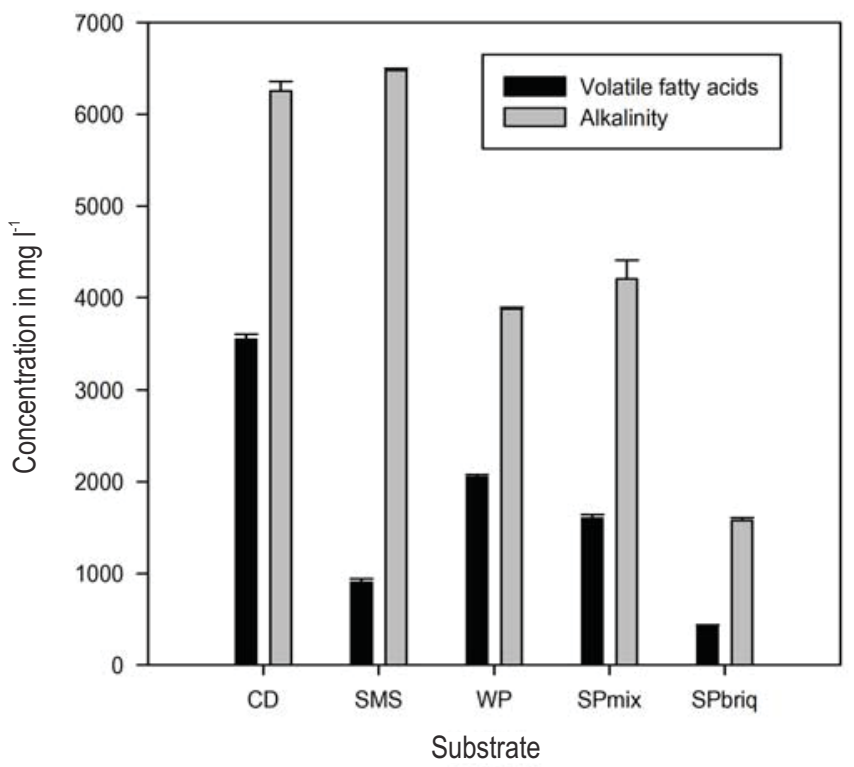

Fig. 6 : Values of volatile fatty acids (VFA) and total alkalinity (TA) of substrates at the end of 60 days digestion. Error bars represent standard deviation of tests done in duplicate

co-digested with spent mushroom substrate. This may be due to reduction in C:N ratio for equal proportion mixture.

Even though the rate of methane production was higher in the initial days for waste paper, as visible in Fig.1, a high C:N ratio led to inhibition of the digestion process thereby reducing the overall methane production. The rate of methane production indicate that a positive impact of digesting waste materials in the inoculum of cow dung can help in production of biogas in a short retention time of 20 days. Similar lesser start up time was observed by previous research on co-digestion of spent mushroom substrate with corn stover (Zhu et al., 2015). Average methane content in gas was the highest (55\%) in cow dung followed by $52 \%$ for spent mushroom substrate. The methane content was $51 \%$ for co-digestion of spent mushroom substrate and waste paper, as powder and briquette followed by $48 \%$ for waste paper as a single substrate. The methane content in waste streams digestion matches with the values of $45 \%$ to $55 \%$ for anaerobic digestion of rice straw (Zealand et al., 2017). The specific methane yield obtained from anaerobic digestion of spent mushroom substrate of $148 \mathrm{ml} \mathrm{CH}_{4} \mathrm{~g}^{-1} \mathrm{VS}$ was found lesser than the result of anaerobic digestion of spent mushroom substrate of $193 \mathrm{ml} \mathrm{CH}_{4} \mathrm{~g}^{-1}$ VS (Temu et al., 2016). The reason for higher yield in literature was due to presence of lipids in the mixed palm oil waste used for mushroom cultivation. Several studies on rice straw digestion with different pretreatment, inoculums and 
temperature produced methane between 92 to $355 \mathrm{ml} \mathrm{CH}_{4} \mathrm{~g}^{-1} \mathrm{VS}$ (Zhou et al., 2017; Mussoline et al., 2013). The reason for yield improvement obtained for spent mushroom substrate in the study can be attributed to delignification of rice straw by the action of ligninolyic mushroom, viz. P.florida (Bisaria et al., 1990). Yen and Brune (2007) reported that the results of co-digestion of algal sludge with waste paper blended at $50 \%$ equal proportion with a C: $\mathrm{N}$ ratio of $18: 1$ and loading rate of $4 \mathrm{~g} \mathrm{VSI}{ }^{-1} \mathrm{~d}$. produced $1170 \pm$ $75 \mathrm{mll}^{-1} \mathrm{~d}$. of methane, while the yield was reduced to $317 \mathrm{ml}^{-1} \mathrm{~d}$. at $75 \%$ paper and $25 \%$ algal sludge and the reason cited was increase in C:N ratio from 18:1 to $36.4: 1$.

Biodegradability of cow dung was observed as $86 \%$ and $80 \%$ for spent mushroom substrate. For waste paper, the process was found inhibited leading to poor degradability of $28 \%$. For spent mushroom substrate-waste paper briquette, the biodegradability was observed as $74 \%$ when compared with the theoretical yield (Fig.3). Biodegradability of spent mushroom substrate-waste paper powder was observed as $50 \%$. Briquetting process has contributed to increase in biodegradability of $24 \%$ more when compared with using them in powder form. The reason could be due to supply of necessary nutrients by spent mushroom substrate in the briquette in slow and prolonged manner making the co-digestion process effective in treating the two hitherto unexploited waste streams. It is presumed that mixing of low nitrogen waste paper stream with high nitrogen substrates like spent mushroom substrate made the mixture a more labile carbon source (Kawai et al., 2012) thereby contributing to favorable biogas yield (Khalid et al., 2011). This presumption of spent mushroom substrate providing impetus to biogas production of waste paper agrees with the findings of Yen and Brune (2007).

The SEM morphology (Fig. 4) showed the presence of lignin indicated by rough surface of untreated rice straw. Smoother surface of the spent mushroom substrate is an indication of disruption of lignin structure and breakdown of cell wall structure which is clearly visible in Fig. 4 (c). Thus, the increased external surface area contributed for the higher hydrolysis efficiency. This indicates that the mushroom production process acted as pretreatment step in size reduction which favored anaerobic digestion. The dense structure visible from the briquetting process further reduced the spent mushroom substrate and waste paper to aid in improving methane yield by better accessibility of high cellulose containing waste paper to the microorganisms. The briquette got disintegrated in the liquid inoculum slowly, thus making more surface area accessible for the microorganisms in a prolonged manner, which could be the reason for higher methane yield in the present study.

The FTIR spectra of spent mushroom substrate in Fig. 5 showed changes in the surface chemistry due to the mushroom production process which acted as a pretreatment of the straw. The major peak observed from spectra of rice straw in the range $1069-1055 \mathrm{~cm}^{-1}$ may possibly be due to $\mathrm{C}=0$ vibrations for alcohol which was unaffected in the spectra of spent mushroom substrate. The broad absorption peaks between $780-540 \mathrm{~cm}^{-1}$ in spent mushroom substrate which is distinct from the spectra of rice straw could be silica structure indicating Si-O-Si bending. This acted favorably in higher availability of cellulose surface for biodegradation by methanogenic bacteria. This is in agreement with the investigation on fungi pretreatment breaking down lignocellulose present in biomass leading to enhanced biogas production (Sharma et al., 2015). Eventhough the carbon content was reduced in the rice straw due to the action of P. florida during cultivation, nitrogen content was intact and incorporated into the mycelial mass (Chanakya et al., 2015). In the present study, mycelium and fungal cell walls were present in spent mushroom substrate contributing to nitrogen content of $1.55 \%$. This balanced the low nitrogen content of $0.13 \%$ in waste paper making the $\mathrm{C}: \mathrm{N}$ ratio of spent mushroom substrate-waste paper combination suitable for anaerobic digestion.

In order to assess the process stability at the end of the digestion period, VFA and alkalinity were determined. VFA concentration in anaerobic reactor indicates stable performance by acetogenic bacteria and effective methanogen population (Wei et al., 2015). A VFA-alkalinity ratio less than 0.4 indicates stable digester performance (Weerayutsil et al., 2016). Comparison of VFA and alkalinity values of different substrates in Fig. 6 showed both spent mushroom substrate and spent mushroom substrate-waste paper briquette as stable process compared to cow dung and waste paper as single substrate and spent mushroom substrate-waste paper in powder form.

It was observed that average VFA value of spent mushroom substrate-waste paper briquette was $417 \mathrm{mg} \mathrm{I}^{-1}$ and alkalinity was $1576 \mathrm{mg} \mathrm{I}^{-1}$ leading to a VFA-alkalinity ratio of 0.26 , which was close to the value of 0.28 (Dussadee et al., 2017). The corresponding value of VFA-alkalinity ratio of spent mushroom substrate-waste paper in powder form was 0.38 , which was close to the maximum level for stable operation. The study with the two hitherto unexploited waste mixtures as briquettes in the biological process of anaerobic digestion showed significant improvement in methane production and stable performance of the digestion process. Wastes in briquette form can provide continuous feedstock supply to existing biogas plants thereby, contributing to clean and renewable fuel production.

\section{Acknowledgment}

Authors are thankful to the Director, National Institute of Technology, Tiruchirappalli for providing the facilities required to perform the research work.

\section{References}

Achinas, S. and G.J.W.Euverink: Theoretical analysis of biogas potential prediction from agricultural waste. Res. Efficient Technol., 2, 143147 (2016).

APHA: Standard Methods for the Examination of Water and Wastewater. $22^{\text {nd }}$ Edn., APHA, AWWA, Washington DC, USA (2012).

Bisaria, R., P. Vasudevan and V.S.Bisaria: Utilisation of spent agro- 
residues from mushroom cultivation for biogas production. Appl. Microbiol. Biotechnol., 33,607-609(1990).

Chanakya, H.N., I.Sharma and T.V.Ramachandra: Micro-scale anaerobic digestion of point source components of organic fraction of municipal solid waste. Waste Manage., 29, 1306-1312 (2009).

Chanakya, H.N., S.Malayil and C.Vijayalakshmi: Cultivation of Pleurotus spp. on a combination of anaerobically digested plant materials and various agro-residues. Energy Sustain. Dev., 27, 84-92 (2015).

Chen,X.,Y. Zhang, Y.Gu, Z.Liu, Z.Shen, H.Chu and X.Zhou: Enhancing methane production from rice straw by extrusion pretreatment. Appl. Energy, 122, 34-41(2014).

Dussadee, N., R.Ramaraj and T.Cheunbarn: Biotechnological application of sustainable biogas production through dry anaerobic digestion of napier grass. 3 Biotechnol., 7, 1-9(2017).

Guo, M. and J.Chorover: Leachate migration from spent mushroom substrate through intact and repacked subsurface soil columns. Waste Manage., 26,133-140(2006).

Holkar, S.K. and R. Chandra: Comparative evaluation of five Pleurotus species for their growth behavior and yield performance using wheat straw as a substrate. J. Environ. Biol., 37, 7-12(2016)

Jha, A.K., C.Sharma, N.Singh, R.Ramesh, R.Purvaja and P.K.Gupta: Greenhouse gas emissions from municipal solid waste management in India mega-cities : A case study of Chennai landfill sites. Chemosphere, 71, 750-758 (2008).

Kawai, M., M.Kishi, M.R.Hamersley, N.Nagao, J.Hermana and T.Todas: Biodegradability and methane productivity during anaerobic codigestion of refractory leachate. Int. Biodeter. Biodegr., 72, 46-51 (2012).

Khalid, A., M.Arshad, M.Anjum, T.Mahmood and L. Dawson : The anaerobic digestion of solid organic waste. Waste. Manage., 31, 1737-1744 (2011)

Mussoline, W., G.Esposito, P. Lens and A.Goirdano : The anaerobic digestion of rice straw: A review. Crit. Rev. Env. Sci. Technol., 43, 895-915(2013).

Ramachandra, T.V., T.K.Subramanian, N.V.Joshi, S.V.Gunaga and R.B.Harikantra : Domestic energy consumption patterns in Uttarakannada district, Karnataka State, India. Energ. Convers. Manage., 41, 775-831(2000).

Sharma, R., S.Singhal, A.K.Tiwari, S.Agarwal, S.Arora and N.Singhal: Influence of pretreatment processes onto bio-methanation of wheat straw. J. Renew. Sustain. Energ., 7, 053109(2015).

Shetty, D.J., P.Kshirsagar, S.T.Maheshwari, V.Lanjekar, S.K. Singh and
P.K. Dhakephalkar : Alkali pretreatment at ambient temperature : A promising method to enhance biomethanation of rice straw. Biores. Technol., 226, 80-88(2017).

Temu, S.G., A.P.Moshi, I.A.Nges, A.M.Mshandete, A.K.Kivaisi and Bo Mattiasson : Mixed palm oil waste utilization through integrated mushroom and biogas production. British Biotechnol. J., 11, 1-12 (2016).

Walter, A., S.Silberberger, M.F.D.Juarez, H.Insam and I.H.franke-Whittle: Biomethane potential of industrial paper wastes and investigation of the methanogenic communities involved. Biotecnol. Biofuels, 9, 1-12(2016).

Weerayutsil, P., U.Khoyun and K.Kuanmar: Optimum ratio of chicken manure and napier grass in single stage anaerobic co-digestion. Energ. Proc., 100, 22-25 (2016).

Wei, B., L.Yuan and W.Liu : The effect of organic loading rate on VFA/ COD ratio for methane production from an EGSB reactor. $J$. Environ. Biol., 36, 1025-1030(2015).

Yadvika, S., T.R. Sreekrishnan, S.Kohli and V. Rana : Enhancement of biogas production from solid substrates using different techniques -Areview. Biores. Technol., 95, 1-10 (2004).

Yan, Z., Z.Song, D.Li, Y.Yuan, X.Liu and T.Zheng: The effects of initial substrate concentration, $\mathrm{C} / \mathrm{N}$ ratio and temperature on solid-state anaerobic digestion from composting rice straw. Biores. Technol., 177, 266-273 (2015).

Yen, H.W and D.E.Brune:Anaerobic co-digestion of algal sludge and waste paper to produce methane. Biores. Technol., 98, 130-134 (2007).

Zealand, A.M., A.P. Rosekilly and D.W.Graham : The effect of feeding frequency and organic loading rate on the anaerobic digestion of Chinese rice straw. Energ. Proc., 105, 62-67 (2017).

Zhang, H., P.Zhang, J.Ye, Y.Wu, W.Fang, X.Gou and G.Zeng: Improvement of methane production from rice straw with rumen fluid pretreatment : A feasibility study. Int. Biodeter. Biodegr., 113, 9-16 (2016).

Zhang, B., G.Tan, Z.Zhong and R.Ruan: Microwave-assisted catalytic fast pyrolysis of spent edible mushroom substrate for bio-oil production using surface modified zeolite catalyst. J. Anal. Appl. Pyrolysis., 123, 92-98(2017).

Zhou, Y., C.Li, I.A.Nges and J.Liu : The effects of pre-aeration and inoculation on solid-state anaerobic digestion of rice straw. Biores. Technol., 224, 78-86(2017).

Zhu, J., M.Han, G.Zhang and L.Yang: Co-digestion of spent mushroom substrate and corn stover for methane production via solid-state anaerobic digestion. J. Renew. Sustain. Energ., 7, 023135(2015). 